\title{
ANALISIS PENGARUH WORD OF MOUTH DAN BRAND IMAGE TERHADAP KEPUTUSAN PEMBELIAN PADA WAROENG SPESIAL SAMBAL "SS" JEMBER
}

\author{
Mochammad Fariz Pradana ${ }^{1}$ \\ Email: mochfariz1695@gmail.com
}

\section{Mohamad Dimyati}

\author{
Ari Subagyo ${ }^{3}$
}

\begin{abstract}
The research aims to analyze influence of work discipline, Work Environment and Work Stress variables to employee performance Akademi Kebidanan Dr. Soebandi Jember. Data is used in this study was primary data obtained from a questionnaire that was given to the respondent. The sampling method used in this study was issaturated with a total sample of 44 respondents. Data analysis method used is multiple linear regression analysis method.The results of this study indicate that discipline significant positive operating environment performance employees Akademi Kebidanan Dr. Soebandi Jember, physical sgnificant positive operating environment performance employees Akademi Kebidanan Dr. Soebandi Jember. Workplace non physical significant positive operating environment performance employees Akademi Kebidanan Dr. Soebandi Jember. Job stress influential significant positive operating environment performance employees Akademi Kebidanan Dr. Soebandi Jember.
\end{abstract}

Keywords: Work Discipline, Employee Performance, Work Environment, Work Stress

\section{PENDAHULUAN}

Pada saat sekarang ini perkembangan dunia kuliner yang semakin kompetitif dan berkembang menuntut setiap pemilik usaha restaurant atau rumah makan harus mampu memainkan strategi pemasaran yang handal dan mampu menarik minat konsumen sehingga mampu memenangkan pasar. Semakin berkembangnya jaman,

1 Corresponding author: Jurusan Manajemen, Fakultas Ekonomi dan Bisnis, Universitas Jember, Jalan Kalimantan No. 37, Kampus Tegalboto, Kecamatan Sumbersari, Jember, 68121, Jawa Timur, Indonesia.

2,3 Jurusan Manajemen, Fakultas Ekonomi dan Bisnis, Universitas Jember, Jalan Kalimantan No. 37, Kampus Tegalboto, Kecamatan Sumbersari, Jember, 68121, Jawa Timur, Indonesia. 
konsumen lebih efektif dalam memilih barang atau jasa yang mereka butuhkan. Konsumen merupakan aspek terpenting dalam penyusunan strategi pemasaran suatu perusahaan sehingga perusahaan perlu membuat dan menerapkan strategi pemasaran yang efektif dan efisien. Dengan strategi pemasaran yang baik diharapkan dapat membuat konsumen memberikan kesan atau image yang baik terhadap perusahaan.

Menurut American Marketing Association dalam (Kotler 2018, 5), "Pemasaran adalah suatu fungsi organisasi dan serangkaian proses untuk menciptakan, mengkomunikasikan, dan memberikan nilai kepada pelanggan dan untuk mengelola hubungan pelanggan dengan cara yang menguntungkan organisasi dan pemangku kepentingannya". Pelanggan merupakan pemakai barang atau jasa yang perlu diperlakukan dengan tepat dan merupakan pasar yang perlu diraih agar profit dapat tercapai.

Aspek yang perlu diperhatikan oleh konsumen yaitu word of mouth (WOM) yang merupakan salah satu strategi pemasaran yang selalu menjadi fenomena yang menarik untuk dibicarakan. Strategi ini biasa disebut dengan promosi dari mulut ke mulut yang mana dipandang sebagai sumber yang lebih dapat dipercaya atau dapat diandalkan dibandingkan dengan informasi dari non personal (Jalilvand dan Samiei 2012). Menurut Jalilvand dalam Wijaya dan Paramita (2014, 12) menerangkan bahwa WOM (word of mouth) berperan besar dalam pengambilan keputusan oleh konsumen dan dalam pembentukan pola perilaku konsumen. Sutisna $(2012,185)$ dalam pandangan tradisional menjelaskan bahwa proses komunikasi word of mouth dimulai dari informasi yang disampaikan melalui media masa, kemudian di informasikan atau ditangkap oleh pemimpin opini yang mempunyai pengikut dan berpengaruh. Puas dan tidak puas nya seorang konsumen sangat berpengaruh terhadap dampak word of mouth baik positif maupun negatif yang akan timbul, sehingga mempengaruhi perusahaan tersebut (Joesyiana 2018).

Aspek yang perlu di perhatikan selanjutnya oleh konsumen yaitu merek. Merek (brand) menurut Asosiasi Pemasaran Amerika dalam Kotler $(2018,332)$ guna mengumpulkan data mendefinisikan merek (brand) sebagai nama, istilah, tanda, simbol atau rancangan atau kombinasi dari semuanya, yang dimaksudkan untuk mengidentifikasi barang dan jasa penjual atau kelompok penjual untuk mendeferensiasikannya dari barang atau jasa pesaing.

Jika para konsumen merasakan citra merek yang bagus, maka akan mendorong mereka melakukan keputusan pembelian terhadap suatu produk dengan merek tertentu, meningkatkan pembelian bahkan menimbulkan keinginan untuk merekomendasikan merek tersebut dan juga menceritakan hal yang baik mengenai merek tersebut terhadap orang lain (Wu et al. 2011). Dan ketika konsumen sudah merasa bahwa produk yang diberikan dapat memberikan kepuasan kepada mereka, maka akan timbul loyalitas dari konsumen tersebut.

Definisi keputusan pembelian adalah kegiatan dimana yang dilakukan oleh konsumen untuk membeli dan mengkonsumsi suatu produk atau jasa dalam rangka untuk memenuhi kebutuhan dan keinginannya (Sumarwan 2011). Dimana ini diasumsikan bahwa semua perilaku sengaja dilandaskan pada keinginan yang dihasilkan ketika konsumen secara sadar dan rasional memilih salah satu diantara tindakan alternatif yang ada. Wijayanti $(2008,140)$ menyatakan bahwa alternatif pilihan konsumen tersebut berkenaan dengan manfaat yang diharapkan dan menyempitkan pilihan hingga alternatif akhir dipilih yang dapat memenuhi dan memuaskan kebutuhan dan keinginannya. 
Salah satu contoh bidang usaha dengan banyak kompetitor yang sama yaitu usaha rumah makan atau restaurant. Usaha rumah makan atau restaurant ini merupakan salah satu usaha yang memang menjanjikan apalagi jika berada pada tempat yang strategis. Seperti halnya Waroeng Spesial Sambal "SS" Jember. Tempat makan ini beralamat di Jalan Danau Toba, Tegal Gede Kecamatan Sumber Sari Kabupaten Jember. Tempat makan ini selalu ramai oleh konsumen. Hal ini karena letak dari tempat makan tersebut yang strategis yaitu dekat dengan kampus dan berada di Kota Jember dimana mayoritas masyarakatnya sangat menyukai kuliner.

Dalam menghadapi persaingan yang semakin ketat dan untuk dapat bertahan di pasar maka Waroeng Spesial Sambal "SS" Jember selalu berusaha memuaskan konsumennya dengan menyuguhkan hidangan dengan aneka sambal yang sangat lezat dengan harapan konsumen akan terpuaskan dan dapat menarik minat konsumen untuk kembali ke tempat makan tersebut. Usaha yang dilakukan oleh pihak manajemen rumah makan dalam menarik konsumen bukan suatu hal yang mudah karena dibutuhkan manajemen strategi yang sangat baik, yaitu memberikan citra yang baik dari Waroeng Spesial Sambal "SS" Jember.Tidak hanya itu, Waroeng Spesial Sambal "SS" Jember juga berusaha menyediakan tempat makan yang nyaman. Penyajian makanan yang dihidangkan dilakukan semenarik mungkin dengan menempatkan setiap jenis menu seperti nasi, lauk, dan sambal di wadah yang berbeda. Hal ini dilakukan dengan tujuan agar konsumen benar-benar dipuaskan dengan penyajian yang diberikan sehingga nantinya timbul kesan positif dari konsumen.

Pada dasarnya, mencari tempat makan yang enak itu mudah tetapi mencari tempat makan yang unik dan memberikan kesan tersendiri di benak konsumen sangatlah tidak mudah. Hal ini dapat disebabkan karena brand image yang coba dibangun oleh pihak perusahaan atau usaha tersentu. Seperti halnya Waroeng Spesial Sambal "SS" Jember. Tempat makan tersebut sudah banyak dikenal oleh masyarakat luas karena selain ada beberapa cabang tidak hanya di Jember, tetapi juga berusaha menyajikan menu dengan penyajian yang unik dengan hidangan berbagai macam sambal yang diutamakan. Hal inilah yang menjadikan kesan tersendiri di benak konsumen yang sudah pernah datang ke Waroeng Spesial Sambal "SS" Jember. Ketika konsumen Waroeng Spesial Sambal "SS" Jember merasa dipuaskan oleh makanan yang dihidangkan oleh Waroeng Spesial Sambal "SS" Jember maka kemungkinan besar mereka akan merekomendasikan tempat makan tersebut kepada orang-orang yang ada di sekitarnya.

Hipotesis dalam penelitian ini antara lain (1) Word of mouth berpengaruh secara signifikan terhadap keputusan pembelian di Waroeng Spesial Sambal "SS" Jember; dan (2) Brand image berpengaruh signifikan terhadap keputusan pembelian di Waroeng Spesial Sambal "SS" Jember.

Adapun rumusan masalah pada penelitian ini adalah (1) Apakah brand image berpengaruh terhadap keputusan pembelian konsumen Waroeng Spesial Sambal "SS" Jember?; Apakah word of mouth berpengaruh terhadap loyalitas pembelian konsumen Waroeng Spesial Sambal "SS" Jember?

Tujuan dari penelitian ini adalah untuk menguji (1) pengaruh brand image terhadap keputusan pembelian konsumen Waroeng Spesial Sambal "SS" Jember; (2) pengaruh word of mouth terhadap keputusan pembelian konsumen Waroeng Spesial Sambal "SS" Jember. 


\section{METODE PENELITIAN}

\subsection{Rancangan atau Desain Penelitian}

Rancangan penelitian ini adalah confirmatory research karena bertujuan untuk sebagai konfimator teori dan juga termasuk dalam jenis explanatory research. Explanatory research yaitu penelitian yang bertujuan untuk menganalisis hubungan hubungan antara satu variabel dengan variabel lainnya atau bagaimana satu variabel mempengaruhi variabel lainnya. Penelitian ini menjelaskan hubungan sebab akibat antara variabel penelitian melalui pengujian hipotesis menggunakan uji t dan uji $F$.

\subsection{Jenis dan Sumber Data}

Pada penelitian ini menggunakan 2 sumber data yaitu sumber data primer dan data sekunder. Data primer adalah data yang diperoleh melalui kusioner yang diberikan pada responden yang dipilih. Data primer dalam penelitian ini diperoleh langsung dari lokasi penelitian dengan memberikan kuesioner kepada responden. Data sekunder dalam penelitian ini adalah data yang diperoleh dari buku, tulisantulisan (dokumentasi) dan laporan dari pakar atau peneliti yang terkait dengan penelitian ini.

\subsection{Populasi dan Sampel}

Populasi penelitian ini adalah konsumen Waroeng Spesial Sambal "SS" Jember. Adapun teknik penarikan sampel dalam penelitian ini adalah metode non probability sampling. Kriteria pengambilan sampel adalah sebagai berikut: (a) konsumen yang telah menikmati makanan di Waroeng Spesial Sambal "SS" Jember; (b) sebaran sampel yang digeneralisasi mulai dari Mahasiswa hingga pekerjaan sesuai dengan populasi. Penelitian ini menggunakan jumlah 10 dikali jumlah indikator yang digunakan dalam penelitian untuk sampel. Mengacu pada pendapat diatas, maka jumlah sampel dalam penelitian ini adalah sebanyak 100 responden

\subsection{Metode Analisis Data}

Metode analisis yang digunakan dalam penelitian ini adalah Confirmatory Factor Analysis (CFA).

\section{HASIL DAN PEMBAHASAN}

\subsection{Karakteristik Responden}

Deskripsi statistik dalam penelitian ini akan mendeskriptifkan data karakteristik berdasarkan umur, jenis kelamin dan pekerjaan. Deskripsi Statistik didapat dari kuesioner yang disebarkan kepada konsumen Waroeng Spesial Sambal "SS" Jember sebanyak 100 kuesioner.

Tabel 1. Karakteristik Responden Berdasarkan Umur

\begin{tabular}{cccc}
\hline No & Usia/umur & Jumlah Responden & Persentase (\%) \\
\hline 1 & $<21$ tahun & 10 & 10 \\
2 & $21-25$ tahun & 34 & 34 \\
3 & $26-30$ tahun & 19 & 19 \\
4 & $31-35$ tahun & 19 & 19 \\
5 & $36-40$ tahun & 13 & 13 \\
6 & $>40$ tahun & 5 & 5 \\
\hline & Jumlah & 100 & 100 \\
\hline
\end{tabular}

Sumber: data primer diolah, 2019 
Tabel 1 menunjukkan bahwa jumlah responden yang berumur $<21$ tahun yaitu sebanyak $10(10 \%)$, responden yang berumur 21 - 25 tahun yaitu sebanyak 34 (34\%), responden yang berumur 26 - 30 tahun yaitu sebanyak 19 (19\%), responden yang berumur 31 - 35 tahun yaitu sebanyak 19 (19\%), responden yang berumur 36 40 tahun yaitu sebanyak $13(13 \%)$ dan responden yang berumur $>40$ tahun yaitu sebanyak $5(5 \%)$.

\begin{tabular}{cccc}
\multicolumn{4}{c}{ Tabel 2. Karakteristik Responden Berdasarkan Jenis Kelamin } \\
\hline No & Jenis Kelamin & Jumlah (Orang) & Persentase (\%) \\
\hline 1 & Laki-laki & 59 & 59 \\
2 & Perempuan & 41 & 41 \\
\hline & Jumlah & 44 & 100 \\
\hline
\end{tabular}

Sumber: data primer diolah, 2019

Tabel 2 menunjukkan bahwa jumlah responden yang paling banyak adalah responden yang berjenis kelamin laki-laki yaitu sebanyak 59 (59\%), Sedangkan responden yang berjenis perempuan yaitu sebanyak 41 orang $(41 \%)$.

\begin{tabular}{cccc}
\multicolumn{2}{c}{ Tabel 3. Karakteristik Responden Berdasarkan Pekerjaan } \\
\hline No & Pekerjaan & Jumlah Responden & Persentase (\%) \\
\hline 1 & Lain-lain & 18 & 18 \\
2 & Mahasiswa & 32 & 32 \\
2 & Pegawai Negeri & 10 & 10 \\
2 & Pegawai Swasta & 12 & 12 \\
2 & TNI & 4 & 4 \\
2 & Wiraswasta & 24 & 24 \\
\hline & Jumlah & 44 & 100 \\
\hline
\end{tabular}

Sumber: data primer diolah, 2019

Tabel 3 menunjukkan bahwa Jumlah responden tingkat pertama (tertinggi) adalah mahasiswa sebanyak 32 orang atau 32\% selanjutnya pada responden tingkat kedua adalah wiraswasta sebanyak 24 orang atu $24 \%$, jumlah responden tingkat ketiga adalah lain-lain sebanyak 18 orang atau 18\%, jumlah responden tingkat keempat adalah pegawai swasta sebanyak 12 orang atau $12 \%$,jumlah responden tingkat kelima adalah pegawai negeri sebanyak 10 orang atau $10 \%$ dan pada tingkat terakhir (terendah) adalah TNI sebanyak 4 orang atau $4 \%$.

\subsection{Analisis Regresi dengan Pendekatan Confirmatory}

Setelah dilakukan uji validitas dan reliabilitas dinyatakan valid dan reliable, data multivariate normal, tidak terjadi multikolinieritas dan outliers, maka variabel tersebut dapat dilanjutkan dengan uji kesesuaian model dan uji signifikansi kausalitas. Hasil pengujian CFA dengan program AMOS 22, memberikan hasil model persamaan struktural yang menunjukkan hubungan antar variabel yaitu :

Dari hasil pengujian tersebut didapatkan persamaan/ model sebagai berikut:

$$
\mathrm{KP}=0,08 \mathrm{WOM}+0,08 \mathrm{BI}+e
$$

a. Uji Kesesuaian Model (Goodness of Fit Test)

Pengujian model pada SEM bertujuan untuk mengukur derajat kesesuian antar model yang dihipotesiskan dengan data yang disajikan. Hasil pengujian kesesuain model dalam penelitian ini disajikan dalam Tabel 4 
Tabel 4. Indeks Keseuaian CFA

\begin{tabular}{cccc}
\hline $\begin{array}{c}\text { Kiteria fit } \\
\text { model }\end{array}$ & Nilai fit model & Standart & Keterangan \\
\hline $\begin{array}{c}\mathrm{X}_{2} \text {-chi- } \\
\text { square }\end{array}$ & 47,399 & $\begin{array}{c}\text { Diharapkan lebih kecil dari X2 } \\
\text { pada } \mathrm{df}=33 \text { yaitu 33,490 }\end{array}$ & Baik \\
$\begin{array}{c}\text { Significance } \\
\text { Probability }\end{array}$ & 0,444 & $\geq 0,05$ & Baik \\
RMSEA & 0,012 & $\leq 0,08$ & Baik \\
GFI & 0,936 & $\geq 0,90$ & Baik \\
AGFI & 0,893 & $\geq 0,90$ & Marginal \\
CMIN/DF & 1,015 & $\leq 2$ & Baik \\
TLI & 0,994 & $\geq 0,95$ & Baik \\
CFI & 0,996 & $\geq 0,95$ & Baik \\
\hline
\end{tabular}

Sumber: data primer diolah, 2019

Berdasarkan Tabel 4 diketahui bahwa dari 8 kriteria yang digunakan untuk menilai layak atau tidaknya suatu model ternyata 1 kriteria marginal dan 7 kriteria baik. Menurut Solimun (2006), jika terdapat satu atau dua kriteria GOF yang telah memenuhi maka model dikatakan baik. Dengan demikian dapat dikatakan model dapat diterima, yang berarti ada kesesuaian antara model dengan data.

b. Uji Kausalitas

Langkah selanjutnya adalah menguji kausalitas yang dikembangkan dalam model 1. Hasil pengujian koefisien jalur disajikan dalam Tabel 5.

Tabel 5. Hasil Pengujian Kausalitas

\begin{tabular}{cccccc}
\hline Pengaruh & Koefisien & Standart Estimate & CR & Prob & Ket. \\
\hline $\mathrm{KK} \rightarrow$ AI & 0,686 & 0,296 & 2,315 & 0,021 & Sig \\
$\mathrm{KK} \rightarrow$ AI & 0,707 & 0,309 & 2,290 & 0,022 & Sig \\
\hline \multicolumn{2}{l}{ Sumber: data primer diolah, 2019} \\
\end{tabular}

Hasil pengujian hipotesis dapat ditampilkan pada Tabel 6:

Tabel 6. Hasil Pengujian Hipotesis

\begin{tabular}{cc}
\hline Hipotesis Penelitian & Keterangan \\
\hline H1 & Berpengaruh (diterima) \\
H2 & Berpengaruh (diterima) \\
\hline
\end{tabular}

Sumber: data primer diolah, 2019

Berdasarkan tabel 6 dapat diketahui bahwa hasil pengujian kausalitas untuk pengaruh variabel word of mouth terhadap keputusan pembelian memiliki koefisien positif sebesar 0,686 dengan c.r sebesar 2,315 dan probabilitas (p) dengan tingkat signifikan 0,05 yaitu sebesar 0,021 yang berarti bahwa word of mouth berpengaruh signifikan terhadap keputusan pembelian di Waroeng Spesial Sambal "SS" Jember. Dengan demikian hipotesis yang menyatakan bahwa variabel word of mouth berpengaruh signifikan terhadap keputusan pembelian terbukti kebenarannya.

Hasil pengujian kausalitas untuk pengaruh variabel brand image terhadap keputusan pembelian memiliki koefisien positif sebesar 0,707 dengan c.r sebesar 2,290 dan probabilitas (p) dengan tingkat signifikan 0,05 yaitu sebesar 0,022 yang berarti bahwa brand image berpengaruh signifikan terhadap keputusan pembelian di Waroeng Spesial Sambal "SS" Jember. Dengan demikian hipotesis yang menyatakan 
bahwa variabel brand image berpengaruh signifikan terhadap keputusan pembelian terbukti kebenarannya.

\subsection{Pengaruh Word of Mouth terhadap Keputusan Pembelian di Waroeng Spesial Sambal "SS" Jember}

Hasil analisis regresi dengan pendekatan confirmatory pada uji kesesuaian model menunjukan bahwa model dapat di terima dan ada kesesuaian antara model dengan data, selanjutnya pada uji kausalitas hipotesis pertama $\left(\mathrm{H}_{1}\right)$ menunjukkan bahwa variabel word of mouth (WOM) berpengaruh signifikan terhadap keputusan pembelian (KP) produk di Waroeng Spesial Sambal "SS" Jember dengan melihat taraf signifikansinya yaitu sebesar 0,021 , yang artinya semakin banyak word of mouth (WOM) maka keputusan pembelian (KP) akan semakin meningkat $\left(\mathrm{H}_{1}\right.$ diterima). Hasil tersebut diperkuat oleh jawaban responden terkait dengan variabel word of mouth (WOM) dan keputusan pembelian (KP) dengan melihat nilai modus yang mengarah terhadap jawaban setuju. Hasil penelitian mengindikasikan bahwa semakin baik word of mouth (WOM) maka semakin tinggi persepsi terhadap keputusan pembelian (KP).

Hasil tersebut diperkuat oleh jawaban dari variabel word of mouth (WOM) dari masing masing indikator yang menjadi faktor penting dalam mempengaruhi keputusan pembelian. Setiap indikator mempunyai hubungan penting terbentuknya keputusan pembelian, salah satunya sebagai berikut:

a. Mendapatkan informasi dalam penelitian ini terlihat jawaban responden cenderung mengarah ke setuju, hal ini dapat di lihat dari nilai modus yang di presepsikan responden terhadap jawaban setuju. Hasil positif inilah yang dapat di jadikan salah satu pedoman bahwa adanya hubungan pada indikator ini yang menunujukan bahwa pengaruhnya terhadap keputusan pembelian di karenakan konsumen ingin produk yang akan di beli jelas sehingga menarik minat konsumen.

b. Motivasi dari orang lain dalam penelitian ini terlihat jawaban responden cenderung mengarah ke setuju, hal ini dapat di lihat dari nilai modus yang di presepsikan responden terhadap jawaban setuju. Hasil positif inilah yang dapat di jadikan salah satu pedoman bahwa adanya hubungan pada indikator ini yang menunujukan bahwa pengaruhnya terhadap keputusan pembelian, ini berpengaruh terhadap keputusan pembelian di karenakan motivasi dari orang lain membuat konsumen terdorong akan menikmati makanan di Waroeng Spesial Sambal "SS" Jember.

c. Rekomendasi dari orang lain dalam penelitian ini terlihat jawaban responden cenderung mengarah ke setuju, hal ini dapat di lihat dari nilai modus yang di presepsikan responden terhadap jawaban setuju. Hasil positif inilah yang dapat di jadikan salah satu pedoman bahwa adanya hubungan pada indikator ini yang menunujukan bahwa pengaruhnya terhadap keputusan pembelian, ini karenakan konsumen mendapat rekomendasi dari orang lain yang dianggap bisa dipercaya sehingga konsumen merasa puas di Waroeng Spesial Sambal "SS" Jember

Hasil Jawaban responden pada deskriptif variabel menunjukan adanya keterkaitan hubungan pada tiap-tiap indikator pada variabel word of mouth (WOM) terhadap keputusan pemebelian (KP). 
Komunikasi yang terjalin antar konsumen sebagai informan dan penerima informasi bersifat positif karena mereka membicarakan, merekomendasikan produk dan mendorong untuk memakai produk Waroeng Spesial Sambal "SS" Jember, sehingga penerima informasi merasa yakin dengan informasi produk yang direkomendasikan. Konsumen memutuskan untuk membeli produk di Waroeng Spesial Sambal "SS" Jember karena mereka sering membicarakan produk tersebut dan direkomendasikan teman dekat atau kerabatnya sehingga konsumen lain terdorong untuk membeli produk tersebut. Oleh karena itu, semakin kuat hubungan antara informan word of mouth dengan penerimanya maka semakin besar pengaruhnya terhadap keputusan pembelian produk produk di Waroeng Spesial Sambal "SS" Jember.

Dalam hal ini konsumen percaya informasi word of mouth dalam memutuskan membeli lebih akurat karena mereka memperoleh informasi dari orang - orang terdekatnya yang sudah pernah membeli produk produk di Waroeng Spesial Sambal "SS" Jember. Menurut Hasan $(2010,230)$ word of mouth merupakan bagian dari strategi promosi dalam kegiatan pemasaran yang menggunakan "orang ke orang" yang puas untuk meningkatkan kesadaran produk dan menghasilkan tingkat penjualan tertentu. Komunikasi dari mulut ke mulut menyebar melalui jaringan bisnis, sosial dan masyarakat yang dianggap sangat berpengaruh.

Word of mouth dapat mempengaruhi seseorang mempersepsikan nilai suatu produk atau persepsi risiko yang akan timbul apabila mengkonsumsi produk tersebut. Persepsi risiko menjadi salah satu komponen penting dalam pemrosesan informasi yang dilakukan konsumen. Apabila produk memberikan kepuasan dan kesan positif, maka word of mouth positif yang kemungkinan akan terjadi dan begitu juga sebaliknya. Dan dengan adanya word of mouth menjadikan konsumen memiliki pengetahuan tentang produk yang akan dipilihnya. Jika konsumen mengathui banyak tentang produk yang akan di pilihnya, maka resiko yang akan ia terima tentunya lebih sedikit daripada ia tidak memiliki pengetahuan tentang produk.

WOM adalah sumber informasi yang independen dan jujur. Artinya ketika informasi datang dari seorang teman atau kerabat lebih kredibel karena tidak ada keterkaitan dari orang tersebut dengan perusahaan pembuat produk Waroeng Spesial Sambal "SS" Jember, sehingga mereka merasa informasi yang di dapatkan lebih riil dan jujur. Hasil penelitian ini sejalan dengan penelitian yang dilakukan oleh Sari dan Yuniati (2016) yang menunjukkan terdapat pengaruh yang signifikan antara variabel word of mouth terhadap keputusan membeli di Waroeng Spesial Sambal "SS" Jember.

\subsection{Pengaruh Brand Image terhadap Keputusan Pembelian di Waroeng Spesial Sambal "SS" Jember}

Hasil analisis regresi dengan pendekatan confirmatory pada uji kesesuaian model menunjukan bahwa model dapat di terima dan ada kesesuaian antara model dengan data, selanjutnya pada uji kausalitas hipotesis kedua $\left(\mathrm{H}_{2}\right)$ menunjukkan bahwa variabel brand image (BI) berpengaruh signifikan terhadap keputusan pembelian (KP) produk di Waroeng Spesial Sambal "SS" Jember dengan melihat taraf signifikansinya yaitu sebesar 0,022, yang artinya semakin baik brand image (BI) maka keputusan pembelian (KP) akan semakin meningkat $\left(\mathrm{H}_{2}\right.$ diterima). Hasil tersebut diperkuat oleh jawaban responden terkait dengan variabel brand image (BI) dan keputusan pembelian (KP) dengan melihat nilai modus yang mengarah terhadap 
jawaban setuju. Hasil penelitian mengindikasikan bahwa semakin baik brand image (BI) maka semakin tinggi persepsi terhadap keputusan pembelian (KP).

Hasil tersebut diperkuat oleh jawaban dari varibel brand image (BI) dari masing masing indikator yang menjadi faktor penting dalam mempengaruhi keputusan pembelian. Setiap indikator mempunyai hubungan penting terbentuknya keputusan pembelian, salah satunya sebagai berikut:

a. Nama baik (reputation) dalam penelitian ini terlihat jawaban responden cenderung mengarah ke setuju, hal ini dapat di lihat dari nilai modus yang di presepsikan responden terhadap jawaban setuju. Hasil positif inilah yang dapat di jadikan salah satu pedoman bahwa adanya hubungan pada indikator ini yang menunujukan bahwa pengaruhnya terhadap keputusan pembelian di karenakan Waroeng Spesial Sambal "SS" Jember memiliki produk yang sudah mendapat kepercayan oleh konsumen warga di Jember

b. Pengenalan (recognition) dalam penelitian ini terlihat jawaban responden cenderung mengarah ke setuju, hal ini dapat di lihat dari nilai modus yang di presepsikan responden terhadap jawaban setuju. Hasil positif inilah yang dapat di jadikan salah satu pedoman bahwa adanya hubungan pada indikator ini yang menunujukan bahwa pengaruhnya terhadap keputusan pembelian di karenakan Waroeng Spesial Sambal "SS" Jember memberikan first impression yang baik kepada masyarakat Jember.

c. Hubungan emosional (affinity) dalam penelitian ini terlihat jawaban responden cenderung mengarah ke setuju, hal ini dapat di lihat dari nilai modus yang di presepsikan responden terhadap jawaban setuju. Hasil positif inilah yang dapat di jadikan salah satu pedoman bahwa adanya hubungan pada indikator ini yang menunujukan bahwa pengaruhnya terhadap keputusan pembelian karenakan Waroeng Spesial Sambal "SS" Jember menyajikan produk yang sesuai dengan masyarakat Jember.

Hasil Jawaban responden pada deskriptif variabel menunjukan adanya keterkaitan hubungan pada tiap-tiap indikator pada variabel brand image (BI) terhadap keputusan pemebelian (KP).

Brand image ketika sudah terbentuk maka kemungkinan konsumen akan merekomendasikan produk tersebut kepada masyarakat yang lebih luas (Hariyana 2013). Hal ini akan sangat membantu perusahaan dalam mempromosikan produk perusahaan sehingga menjadi lebih efektif dan efisien. Konsumen merasakan citra merek yang bagus, maka akan mendorong mereka melakukan keputusan pembelian terhadap suatu produk dengan merek tertentu, meningkatkan pembelian bahkan menimbulkan keinginan untuk merekomendasikan merek tersebut dan juga menceritakan hal yang baik mengenai merek tersebut terhadap orang lain. Oleh karena itu, semakin kuat brand image yang di miliki perusahaan maka semakin besar pengaruhnya terhadap keputusan pembelian produk produk di Waroeng Spesial Sambal "SS" Jember.

Menurut Kotler $(2018,54)$ citra merek adalah suatu persepsi dan keyakinan yang dipegang oleh konsumen, seperti yang dicerminkan asosiasi yang tertanam dalam ingatan konsumen. Disini perusahaan dituntut untuk lebih berinovasi sehingga mampu bersaing dan mampu menerima tantangan pasar untuk menanamkan produk barang atau jasa yang dimiliki perusahaan kedalam benak konsumen sehingga 
produk yang dimiliki memiliki keunikan dan ciri khas agar tidak mudah ditiru oleh para pesaing-pesaingnya.

Brand image adalah sumber informasi yang independen dan jujur. Artinya ketika informasi datang dari seorang teman atau kerabat lebih kredibel karena tidak ada keterkaitan dari orang tersebut dengan perusahaan pembuat produk Waroeng Spesial Sambal "SS" Jember, sehingga mereka merasa informasi yang di dapatkan lebih riil dan jujur. Hasil penelitian ini sejalan dengan penelitian yang dilakukan oleh Harahap (2013) yang menunjukkan terdapat pengaruh yang signifikan antara variabel brand image terhadap keputusan membeli di Waroeng Spesial Sambal "SS" Jember.

\section{KESIMPULAN}

Berdasarkan analisis yang telah dilakukan pada penelitian ini, maka dapat diambil kesimpulan sebagai berikut: (1) Word of mouth berpengaruh positif signifikan terhadap keputusan pembelian konsumen di Waroeng Spesial Sambal "SS" Jember karena word of mouth telah memenuhi kebutuhan dan harapan karena konsumen telah melakukan keputusan pembelian produk di Waroeng Spesial Sambal "SS" Jember; dan (2) Brand image berpengaruh positif signifikan terhadap keputusan pembelian konsumen di Waroeng Spesial Sambal "SS" Jember karena konsumen telah memenuhi kebutuhan dan harapan karena konsumen telah melakukan keputusan pembelian produk di Waroeng Spesial Sambal "SS" Jember.

\section{DAFTAR PUSTAKA}

Harahap, M. A. K. 2013. Analisis Pengaruh Brand image Dan Word of mouth (WOM) Terhadap Proses Keputusan Pembelian Handphone Blackberry (Studi Kasus Pada Mahasiswa FE UNY). Skripsi. Yogyakarta: Fakultas Ekonomi Universitas Negeri Yogyakarta.

Hariyana, N. 2013. Pengaruh Penggunaan Iklan Endorser Produk Sabun Luxmediatelevisi Terhadap Keputusan Pembelian dan Loyalitas Merek pada Konsumen Produk Sabun Lux di Kabupaten Jember. JURNAL EKONOMI AKUNTANSI DAN MANAJEMEN 12 (2):1-28.

Hasan, A. 2010. Marketing dari mulut ke mulut. Yogyakarta: Media Pressindo.

Jalilvand, M. R., dan N. Samiei. 2012. The effect of electronic word of mouth on brand image and purchase intention. Marketing Intelligence \& Planning.

Joesyiana, K. 2018. Pengaruh Word of Mouth Terhadap Keputusan Pembelian Konsumen pada Media Online Shopee di Pekanbaru (Survey pada Mahasiswa Semester VII Jurusan Pendidikan Akuntansi Fakultas Keguruan dan Ilmu Pendidikan Universitas Islam Riau). Jurnal Valuta 4 (1):71-85.

Kotler, P. 2018. Manajemen pemasaran jilid 1. Edisi 13 ed. Jakarta: Erlangga.

Sari, F. P., dan T. Yuniati. 2016. Pengaruh harga citra merek dan word of mouth terhadap keputusan pembelian konsumen. Jurnal Ilmu dan Riset Manajemen $5(6): 1-15$.

Sumarwan, U. 2011. Perilaku konsumen: Teori dan penerapannya dalam pemasaran. Bogor: Ghalia Indonesia.

Sutisna. 2012. Perilaku Konsumen dalam Komunikasi Pemasaran. edited by E. Kedua. Bandung: Remaja Rosdakarya. 
Wijaya, T., dan L. Paramita. 2014. Pengaruh Electronic Word of Mouth (eWOM) Terhadap Keputusan Pembelian Kamera DSLR.

Wijayanti, A. 2008. Strategi meningkatkan loyalitas Melalui kepuasan pelanggan (studi kasus: produk kartu seluler prabayar Mentari indosat wilayah semarang), program Pascasarjana Universitas Diponegoro.

Wu, P. C., G. Y.-Y. Yeh, dan C.-R. Hsiao. 2011. The effect of store image and service quality on brand image and purchase intention for private label brands. Australasian Marketing Journal (AMJ) 19 (1):30-39. 